\title{
Landscape structure in the Pirapó, Paranapanema 3 and 4 Hydrographic Unit, in the state of Paraná, Brazil
}

\author{
M. T. Nóbrega ${ }^{a *}$, E. Serra ${ }^{a}$, H. Silveira ${ }^{a}$, P. M. B. Terassi ${ }^{a}$ and C. M. Bonifácio ${ }^{a}$ \\ aPrograma de Pós-graduação em Geografia, Departamento de Geografia, Universidade Estadual de Maringá - UEM, \\ Av. Colombo, 5790, Jd. Universitário, CEP 87020-900, Maringá, PR, Brazil \\ *e-mail: mtnobrega@uol.com.br
}

Received: January 17, 2015 - Accepted: May 20, 2015 - Distributed: November 30, 2015

(With 11 figures)

\begin{abstract}
The aim of this study is to characterize the Pirapó, Paranapanema 3 and 4 Hydrographic Unit, emphasizing its physical attributes and processes of use and occupation, responsible for the structure of the current landscape and the state of its water resources. The recognition of the landscape's spatial structure in the hydrographic unit and its drainage basins was obtained by integrated analysis of the main elements that compose it: geology, landforms (hypsometric and slope), soils, climate and land use. Analysis revealed that within each drainage basin several variations in the spatial structure of the landscape occur which produce an internal compartmentalization. Each compartment is defined by its own geo-ecological structure, physiognomic standards and dynamics, reflected in its potentialities and vulnerabilities and in the conditions of water resources in the wake of occupation and use over time.
\end{abstract}

Keywords: drainage basin, geo-ecological structure, land use, compartments, northern region of the Paraná State.

\section{Estrutura da paisagem na Unidade Hidrográfica Pirapó, Paranapanema 3 e 4, no estado do Paraná, Brasil}

\section{Resumo}

O objetivo deste trabalho é caracterizar a Unidade Hidrográfica do Pirapó, Paranapanema 3 e 4, ressaltando os seus atributos físicos e os processos de uso e ocupação, responsáveis pela estrutura da paisagem atual e pelo estado dos seus recursos hídricos. O reconhecimento da estrutura espacial da paisagem na unidade hidrográfica e nas suas bacias foi obtido por meio da análise integrada dos principais elementos que a compõe: geologia, relevo, solos, clima e uso da terra. A análise mostrou que no interior de cada bacia hidrográfica ocorrem variações na estrutura espacial da paisagem que produzem uma compartimentação interna. Cada compartimento se define por uma estrutura geoecológica, padrões fisionômicos e dinâmicos próprios o que se reflete nas suas potencialidades e vulnerabilidades e nas condições dos seus recursos hídricos, em face das formas de ocupação e uso ao longo do tempo.

Palavras-chave: bacia hidrográfica, estrutura geoecológica, uso da terra, compartimentos, norte do Paraná.

\section{Introduction}

In the state of Paraná, as part of the State Water Resources Policy, sixteen drainage basins were delineated and, based on physiographic criteria, created twelve Hydrographic Units Water Resources Management. The Pirapó, Paranapanema 3 and 4 Hydrographic Unit, linked to the Piraponema Basin Committee established in 2008, is one of the units and the object of the current analysis.

Due to its size and its geographical location, the above-mentioned hydrographic unit presents an important geological diversity with regard to landforms, climate, soil and original vegetation whose integration generates spaces with distinct strengths and vulnerabilities in view of the processes of use and occupation. Human occupation and economical usage of natural resources have transformed the environment and introduced new structures that altered the functioning and the behavior of the original systems. In terms of quantity and quality, the state of water resources is also due to the integration of natural factors modified by populations in their historical process of occupation and economic development.

Current analysis characterizes the Pirapó, Paranapanema 3 and 4 Hydrographic Unit, with special reference to its physical qualities and the processes of use and occupation, which caused the present landscape structure and, therefore, the conditions of its water resources.

\section{Material and Methods}

The Pirapó, Paranapanema 3 and 4 Hydrographic Unit is part of Paraná River Basin. It lies in the northern area of the state of Paraná, Brazil, within the tropics. In fact, the 
Tropic of Capricorn passes through its southern section. The unit is composed of tributaries from the left margin of the Paranapanema River, divided into three drainage basins: The Pirapó, Paranapanema 3 and Paranapanema 4 drainage basins (Figure 1).

According to the Secretariat for the Environment and Water Resources of the state of Paraná (Paraná, 2010), the Pirapó basin is the biggest in extension, with an area of $5,089.10 \mathrm{~km}^{2}$. The Pirapó River is $168 \mathrm{~km}$ long and has approximately 60 tributaries. The Bandeirantes River, $106 \mathrm{~km}$ long, is its greatest tributary. The Paranapanema 3 basin, east of the Pirapó basin, has an area of $3,564.30 \mathrm{~km}^{2}$ and is formed by twelve direct tributaries from the Paranapanema River, which flows into the section between the mouth of the Tibagi River and the mouth of the Pirapó River. Among them the streams Vermelho (the longest), Caneleira, Tenente and Santo Inácio, should be highlighted. The Paranapanema 4 basin, west of the Pirapó basin, comprises $4,134.90 \mathrm{~km}^{2}$, with fifteen direct tributaries from the Paranapanema River. The most important tributaries are the streams: Tigre, Corvo, Coroa do Frade, Caiue and Francisco or Diabo.
The three basins are extensive to the total or partial territory of 57 municipalities and part of the metropolitan areas of Maringá and Londrina. Water demand of the population and their activities in the drainage basins is largely attended by surface water (respectively $75 \%$ and $81 \%$ from the Pirapó and Paranapanema 3 basins). On the other hand, $53 \%$ of water from Paranapanema 4 basin originates from underground water reserves (Paraná, 2010).

Throughout the hydrographic unit, the Paranapanema River is controlled by dams of the Capivara and Taquaruçu hydroelectric plants within the stretch between the Paranapanema 3 basin, and the Rosana dam in the Paranapanema 4 basin.

The recognition of the landscape's spatial structure in the hydrographic unit and its drainage basins was obtained by integrated analysis of the main elements that compose it: geology, landforms (hypsometric and slope), soils, climate and land use. Thematic maps were prepared, some of which from extant cartography, as in the case of geology (MINEROPAR, 2006) and soils (EMBRAPA, 2008), others for geoprocessing SRTM (Shuttle Radar Topographic Mission) images made available by the Topodata Project of the National Institute of Spatial Research (INPE),

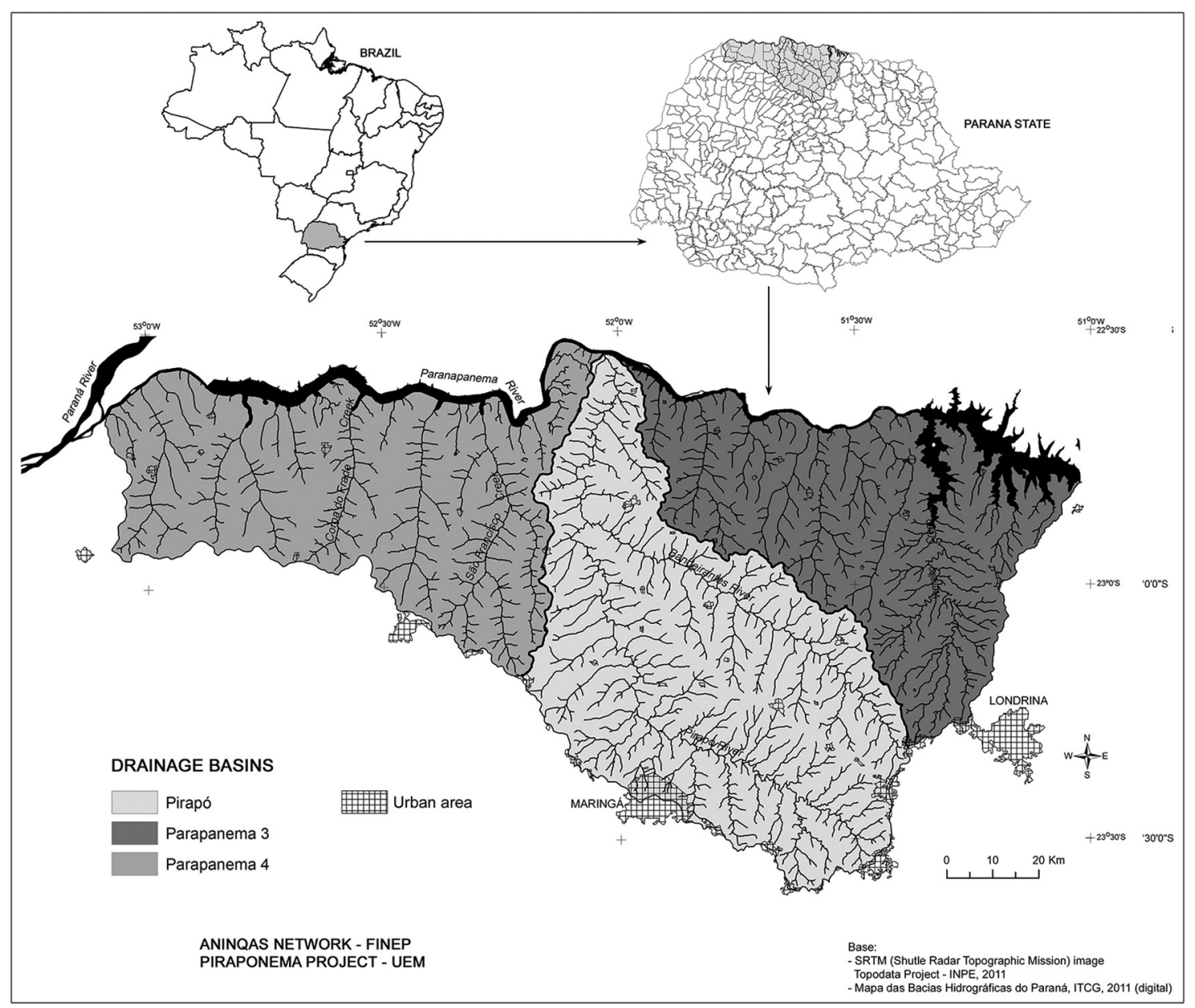

Figure 1. The hydrographic unit and its drainage basins. 
such as hypsometry and slope gradient, applying the methodologies presented on Valeriano (2008). In the case of the slope map, the classification suggested by Ross (1994) was adopted: 0-6\%, 6-12\%, 12-20\%, 20-30\% and $>30 \%$. Maps were prepared with ArcGIS 9 and subjected to control in the field.

Climatic conditions were identified and characterized by average monthly rainfall rates from 1972 to 2012 . They were obtained at 35 rainfall stations collected by the Superintendence for the Development of Water Resources and Environmental Sanitation of the state of Paraná, Brazil, and from four meteorological stations, three of which comprise the Agronomic Institute of Paraná (IAPAR) network (Apucarana, Bela Vista do Paraíso and Paranavaí) and one from the National Institute of Meteorology (INMET) network (Maringá). Data were analyzed at yearly and seasonal scales: January, February and March correspond to summer; April, May and June to autumn; July, August and September to winter and October, November and December to spring.

Due to scarcity of temperature data throughout the drainage basins, estimates of mean monthly temperatures were undertaken by applying the method by Ometto (1981) with a variation of $0.65^{\circ} \mathrm{C}$ at every $100 \mathrm{~m}$ altitude. The climatologic stations of Apucarana, Bela Vista do Paraíso, Maringá and Paranavaí provided temperature estimates at rainfall stations. Rainfall and temperature data were provided in isohyets and isothermal charts prepared with Surfer 7 .

Map of land use was generated by classification of Landsat TM 5 images captured on 04/10/2011 and 05/19/2011, provided by INPE. The following usages were mapped by Program ArcGIS 9: forest vegetation (native or reforestation), crops (seasonal and perennial), pastures and urban areas.

Information on space occupation and land use were supplemented by field surveys.

\section{Results and Discussion}

\subsection{Geological substratum, landforms and soils}

The Pirapó, Paranapanema 3 and 4 Hydrographic Unit corresponds to a segment of the Paraná Sedimentary Basin composed of rocks of the Serra Geral Formation (São Bento Group), partially covered by rocks of the Caiuá, Santo Anastácio and Adamantina formations (Bauru Group) - Figure 2.

The Serra Geral Formation, with overlaid basaltic lava flows and small intercalated sandstones layers, originated by volcanic events from the Jurassic to the Cretaceous periods (Melfi et al., 1988). The region in which the hydrographic unity lies is predominantly made up of tholeiitic basalt and andesi-basalt with high titanium rates (Piccirillo et al., 1988). Associated to lava flows, diabase dikes and sills with variable thicknesses occur. Dikes are often oriented in NW-SE direction, following the structural lineaments related to the Ponta Grossa arch.

The basalts outcrop in $38 \%$ of the area and are distributed on the eastern section of the Paranapanema 3 basin and the central-south section of the Pirapó basin. The basalts outcropping at the highest sectors and throughout the valleys of the Pirapó and Bandeirantes rivers and streams of the Paranapanema 3 basin is a result of the inclination of layers towards the NW. It is due to a strong subsidence that affected the region adjacent to the Paraná River's channel, especially within the territory of the state of São Paulo, Brazil, and faults after lava flows (Fernandes, 1998).

The subsidence movements gave rise to Bauru Basin where the Bauru Group rocks were deposited, with the Serra Geral Formation as substratum (Fernandes, 1998; Paula-Silva et al., 2003). Consequently, sedimentary layers are thicker when facing the more depressing zones and thinner when facing the edges. The above explains relationships between the different formations of the Bauru

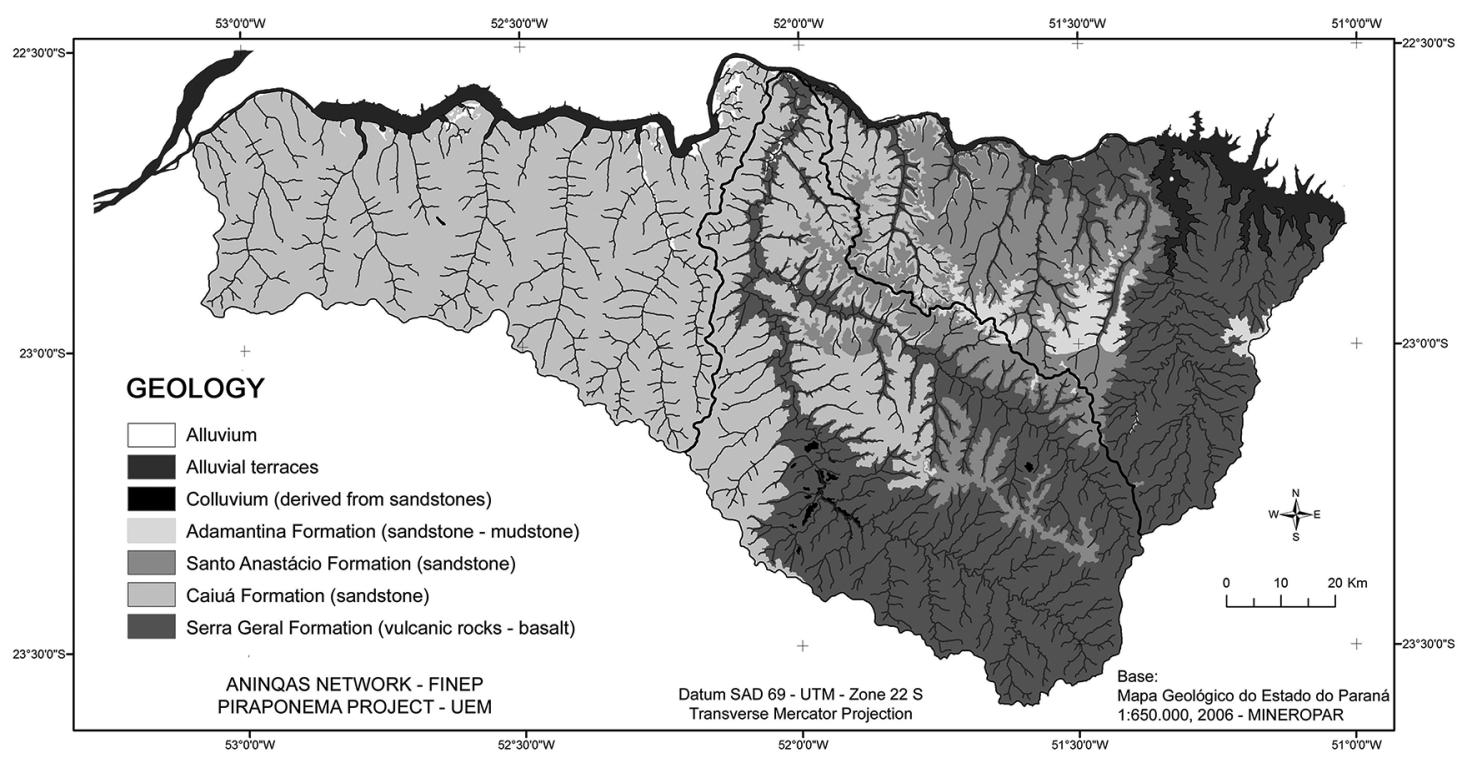

Figure 2. Geological map of the Pirapó, Paranapanema 3 and 4 Hydrographic Unit. 
Group and their contacts with the Serra Geral Formation in the hydrographic unit area. The Bauru Group in the area under analysis has the following stratigraphic sequence:

- The Caiuá Formation originated in wind and fluvial environment. It is characterized by fine to medium purple-colored sandstones with large-size crossed stratification (MINEROPAR, 2001). It is the most relevant geological formation, covers $46 \%$ of the whole area, and occurs throughout the Paranapanema 4 basin, in $31 \%$ of the Pirapó basin (middle and low sections) and $9 \%$ of the Paranapanema 3 basin (northwestern section).

- The Santo Anastácio Formation lies within the central-eastern sector of the hydrographic unit, comprising $13 \%$ of the area. It covers the Caiuá Formation and laterally as it goes east and southeast of the unit, appears seated directly on the Serra Geral Formation (Figure 2). It occurs in $11 \%$ of the Pirapó basin area and in 30\% of the Paranapanema 3 Basin. It is present in $11 \%$ of the area of the Pirapó basin and in $30 \%$ of Paranapanema 3 . Formed in floodplain environment consists of very fine to medium sandstones, with some beds of reddish mudstones, showing cross- bedding and plane-parallel (MINEROPAR, 2001).

- The Adamantina Formation lies on the Santo Anastácio Formation in the region, with the exception of a small spot (in the east) where it appears directly on the basalts of the Serra Geral Formation. Very fine to fine sandstones overlaid with mudstone and silt banks, showing cross-bedding and plane-parallel, also originated in a floodplain environment (MINEROPAR, 2001). The formation's main difference is the lateral and vertical variability of lithofacies (Paula-Silva et al., 2003). It mostly occurs in the Paranapanema 3 basin, featuring approximately $7 \%$ of the basin's area, whereas it is less than $1 \%$ in the Pirapó and absent in Paranapanema 4 basin. The formation in the hydrographic unit is present in only $2 \%$ of its entire extension.

Localized Quaternary deposits are also reported. The most extensive are floodplain deposits along the Paranapanema River and some isolated spots of colluvial deposits derived from sandstones of the Caiuá and Santo Anastácio formations that locally overlie the basalts.

The drainage network on this geological substratum features low density $\left(<0.50 \mathrm{~km} / \mathrm{km}^{2}\right)$, although it is comparatively denser on the volcanic rocks in the Pirapó and Paranapanema 3 basins with a dendritic pattern (Figures 2 and 3). The parallel pattern is dominant in sandstones (Caiuá, Santo Anastácio and Adamantina formations) especially in the Paranapanema 4 basin that has the lowest density of the three basins.

The hydrographic unit's landforms reflect the integration between the geological substratum (lithology and structures) and the carving produced by that drainage network (Figures 3 and 4).

Most of landforms comprise heights from 300 to $500 \mathrm{~m}$, displaying a hilly landscape. The hills range from large to medium sizes, with wide, flattened or rounded tops, long hillsides with gentle slopes, which tend to accentuate in the lower segments. However, as it goes east and southeast of the area, especially at the interfluves between Pirapó and Ivaí drainage basins, the altitudes becomes higher and exceeds $900 \mathrm{~m}$ in some places (headwaters from the Pirapó River). In those sectors, the hills have narrower tops and hillsides are shorter with relatively higher slopes.

Step-slopes are also frequent especially in the outcropping basalt areas (sectors of the upper Pirapó and Paranapanema 3) alternating straight segments with

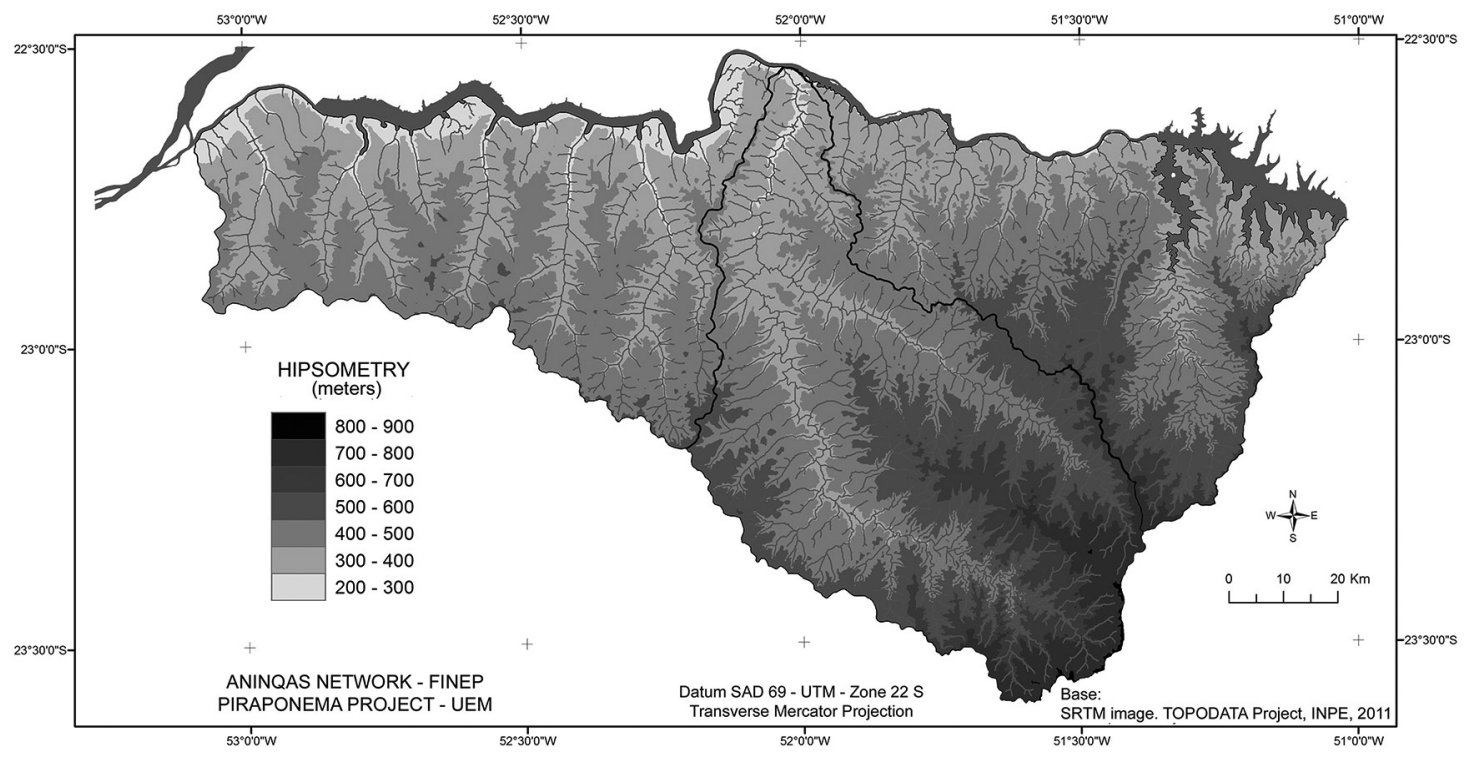

Figure 3. Hypsometric map of the Pirapó, Paranapanema 3 and 4 Hydrographic Unit. 
steep slopes and inclined segments of gentle slopes and / or moderate slopes.

Since they are subjected to climatic processes under humid tropical conditions, landforms and rocks produced a pedological covering, in which prevail dystrophic and dystroferric Red Latosols associated with dystrophic Red Argisols and eutropherric Red Nitosols. Other types of soil occur, such as eutrophic and eutroferric Red Latosols also occur, although in small and dispersed spots. Litholic Neosols, generally linked to steep slopes, are more frequently found in the Pirapó basin, whereas Gleysols often found along watercourses, also occur as an enlarged and continuous spot within a significant segment of the Paranapanema 3 basin (Figure 5). Establishing a correspondence with the soil classification system adopted by the FAO (WRB, 2006) the Latosols, Argisols, Nitosols, Litholic Neosols and Gleysols could be correlated to the classes Ferralsols, Acrisols, Nitisols, Leptosols and Gleysols, respectively.

Latosols have an advanced stage of weathering, are thick, porous and well drained soils with poor mobility of clays in the B horizon. They are generally acid, with a low cation exchange capacity and base saturation (dystrophic). Latosols are homogeneous in their characteristics and attributes along the profile, with diffuse or gradual transitions under and above the horizons. They occur usually associated with flat to gentle undulating topography (EMBRAPA, 2013). On the one hand, these characteristics favor rainwater infiltration and the filling of underground

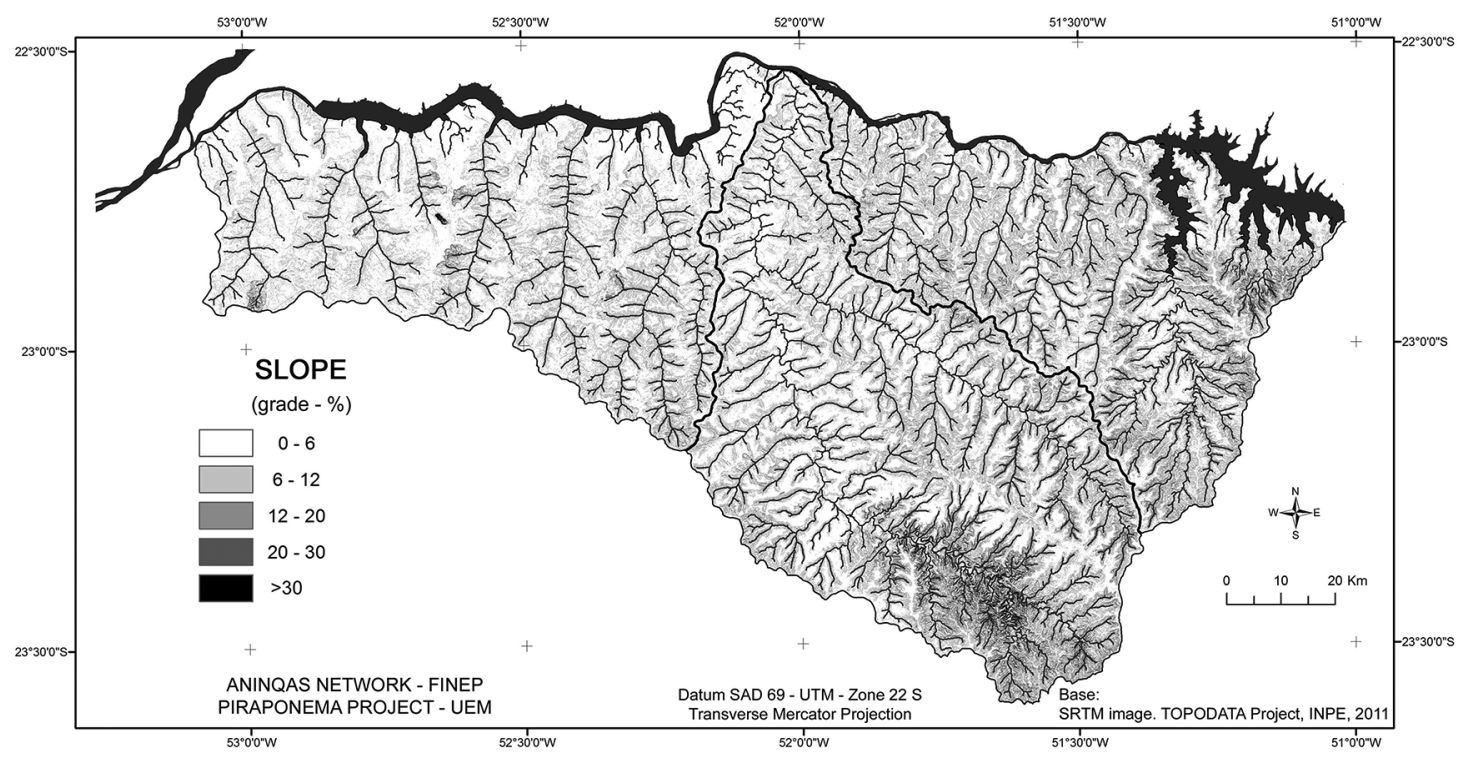

Figure 4. Map of slopes of the Pirapó, Paranapanema 3 and 4 Hydrographic Unit.

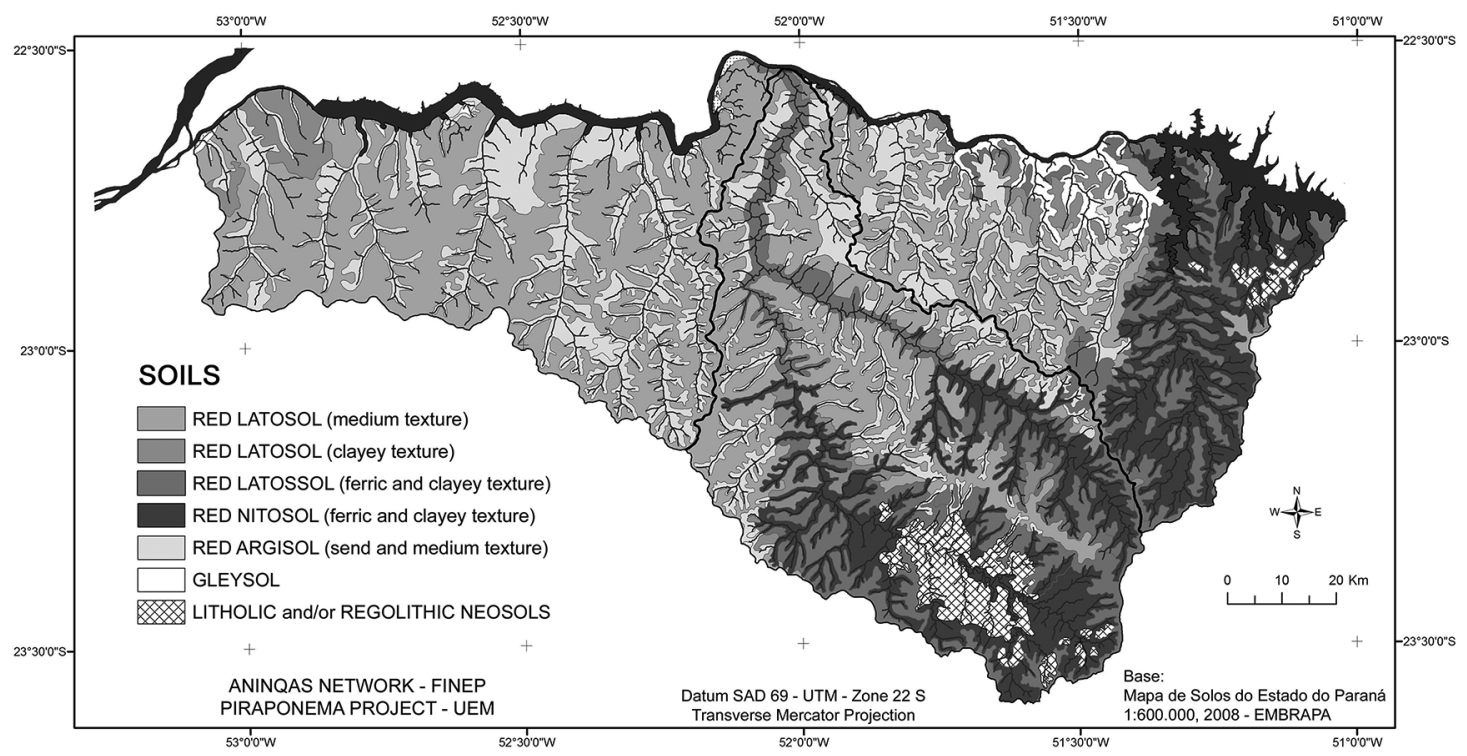

Figure 5. Map of the soils of the Pirapó, Paranapanema 3 and 4 Hydrographic Unit. 
water reservoirs and, on the other hand, they reduce the susceptibility to erosion.

The class of Red Latosols in the area has two main groups: medium texture group (clay fraction $<35 \%$ ), which mainly corresponds to dystrophic or eutrophic (at a lower proportion) Red Latosols derived from weathering in the sandstones (Caiuá, Santo Anastácio and Adamantina formations); and the clayey texture group (35\% to $60 \%$ of clay) or more frequently very clayey texture group ( $>60 \%$ of clay), which corresponds to classes of dystroferric or eutroferric (more restricted) Red Latosols, derived from basalts. Some rather small spots of eutrophic Red Latosols occur in the Latosol group of clayey texture.

As a rule, Latosols extend generally over surfaces with gentle slope and well drained, with a high occurrence on wide hills, covering from the top to the middle or lower-middle slope, as has been reported in the Paranapanema 4 basin. In the areas of medium to small hills (Paranapanema 3 basin and mid-sector of the Pirapó basin) Latosols are more restricted to the tops and upper slopes. Those of clayey or very clayey texture are naturally more fertile and less susceptible to erosion, whereas those with medium texture have lower fertility and are relatively more susceptible to erosion (Bigarella and Mazuchowski, 1985; Fasolo et al., 1988; Ker, 1998).

Eutroferric Red Nitosols occur in basalt area, associated with dystropherric or eutroferric Red Latosols, covering part of the hillslopes, usually in the middle and lower slope sector. When the terrain is somewhat more dissected, as in the upper Pirapó basin and across the eastern sector of the Paranapanema 3 basin (mid-sized and small hills), Nitosols advance to the top and cover the hillslopes. In some cases, they cover the top and prevail extensively over the whole areas.

Nitosols have variable thickness, usually from 1.50 to $3.0 \mathrm{~m}$, are clayey or very clayey, and show no great textural contrast between horizon A and B. However, although the soils are well drained, their physicochemical and structural features (polyhedral aggregates) become naturally denser and with a predominantly fissural porosity. Sometimes they have a retractable trait that may decrease their permeability (EMBRAPA, 2013).

Such characteristics may reduce water infiltration on the soils and increase surface runoff which, when linked to landforms conditions (steeper slopes), make them more susceptible to water erosion when compared to Latosols, as found by Fasolo et al. (1988).

Litholic and/or Regolithic Neosols also lie on the basalts where terrain dissection is more pronounced and hillsides exhibit steeper slopes. In fact, they are shallow, poorly developed soils, consisting by horizons A-C or A-R (EMBRAPA, 2013). Rocks and/or rocky blocks close to the surface hinder their agricultural use, but also the possibility of quick formation of surface water flow and, consequently, favor erosion.

Red Argisols with medium texture only occur on sandstones (Caiuá, Santo Anastácio and Adamantina formations) and in the sandstones-basalt contact zones.
In the areas of large hills (Paranapanema 4 basin) they are restricted to the sectors of middle and lower hillslopes. Argisols may be found higher up on the hillsides and sometimes even cover the hill top in regions with mid-sized and small hills, as in the Paranapanema 3 basin where the slopes are steeper.

Argisols have variable thicknesses; they are well drained, with an important textural gradient between the surface horizons (A and E) and Bt (EMBRAPA, 2013). Textural gradient (sandy A and $\mathrm{E}$ horizons over a more clayey Bt horizon) also means difference in porosity and permeability between horizons. Thus, the more clayey $\mathrm{Bt}$ reduces the infiltration capacity, and promotes rapid saturation of the sandy horizons above, favoring the action of surface water runoff and conferring these soils a greater susceptibility to erosion (Cunha, 2002).

Quartzarenic Neosols are common in sandstones-dominating regions, at headwaters and at the foot of slopes. Although they are frequent, their spots do not appear on the maps due to the scale adopted (Figure 5). Quartzarenic Neosols are sandy ( $<15 \%$ clay fraction) and composed of horizons A-C, without any lithic contact at a depth of less than $150 \mathrm{~cm}$ deep (EMBRAPA, 2013). The lack of cohesion (sand) and position in the landscape make these materials very susceptible to erosion.

Fasolo et al. (1988) conducted a study in most of the hydrographic unit and classified soils according to their susceptibility to erosion. Based on these authors, Red Latosols with clayey texture are in slight susceptibility to erosion class. Most medium texture Red Latosols have moderate susceptibility and turn into slight susceptibility to erosion as the clay content increases. Red Nitosols may be classified as moderate, whereas Argisols have moderate to very strong susceptibility to erosion. In fact, they depend on textural contrast (abrupt) under and below the horizons and steepness of the slopes. Quartzarenic and Litholic and/or Regolithic Neosols have a strong to very strong susceptibility to erosion. Due to steeper slopes and mainly to land use susceptibility increases.

\subsection{Climate conditions}

Climatic analysis in the Pirapó, Paranapanema 3 and 4 Hydrographic Unit shows that mean annual rainfall ranges from $1250 \mathrm{~mm}$ to $1600 \mathrm{~mm}$ (Figure 6).

The Pirapó Basin has the highest mean annual rainfall rates, followed by the Paranapanema 3 and 4 basins, respectively with $1498.6 \mathrm{~mm}, 1439.3 \mathrm{~mm}$ and $1377.6 \mathrm{~mm}$. Rainfall tends to decrease towards the north and northwest where the lowest yearly rainfall rates were reported (from $1250 \mathrm{~mm}$ to $1300 \mathrm{~mm}$ ), at the banks of the river Paranapanema in low altitude areas, close to 300 meters. Highest mean yearly rainfall rates (ranging from $1500 \mathrm{~mm}$ to $1600 \mathrm{~mm}$ ) occur on high land of the hydrographic unit's watersheds, with altitudes from $450 \mathrm{~m}$ to $900 \mathrm{~m}$ (Figure 3).

Two factors actually affect rainfall distribution in the area under analysis. The first factor, of a dynamic nature, comprises the atmospheric circulation by working systems; the second, of a static nature, comprises the area's orography. 
Spatial distribution of rainfall during the four seasons is similar to that observed on a yearly scale. In other words, rainfall is more abundant in all seasons upstream in the southern, southwestern and southeastern sectors and less abundant downstream in the northern and northwestern sectors. Summer is the rainiest season, followed by spring, autumn and winter. The latter is the driest season, as show in Figure 7.

Mean seasonal rainfall rates in the hydrographic unit show that rainfall varies from $480 \mathrm{~mm}$ to $540 \mathrm{~mm}$
(Figure 7A) in the summer and from $445 \mathrm{~mm}$ to $470 \mathrm{~mm}$ during spring (Figure 7C).

During autumn, average rainfall varies approximately from $308 \mathrm{~mm}$ to $400 \mathrm{~mm}$ (Figure 7D) and from $180 \mathrm{~mm}$ to $290 \mathrm{~mm}$ during the drier winter period (Figure 7B).

The Paranapanema 3 basin has the highest rainfall rates during summer, with $498.9 \mathrm{~mm}$; the Pirapó basin with $494.9 \mathrm{~mm}$ and the Paranapanema 4 basin with $448.6 \mathrm{~mm}$. The Pirapó River basin has the highest amount of rain, with

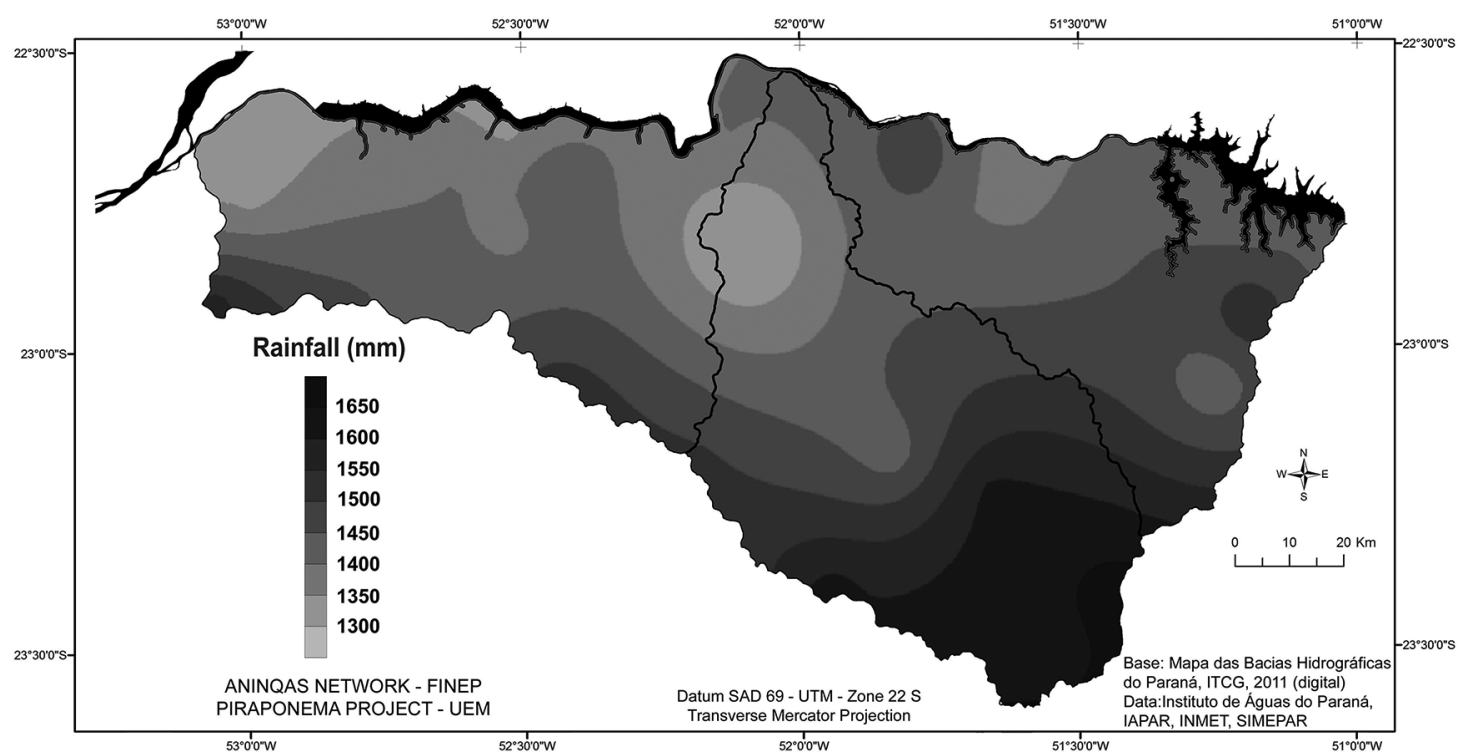

Figure 6. Spatial distribution of average yearly rainfall in the Pirapó, Paranapanema 3 and Paranapanema 4 Hydrographic Unit from 1976 to 2012.

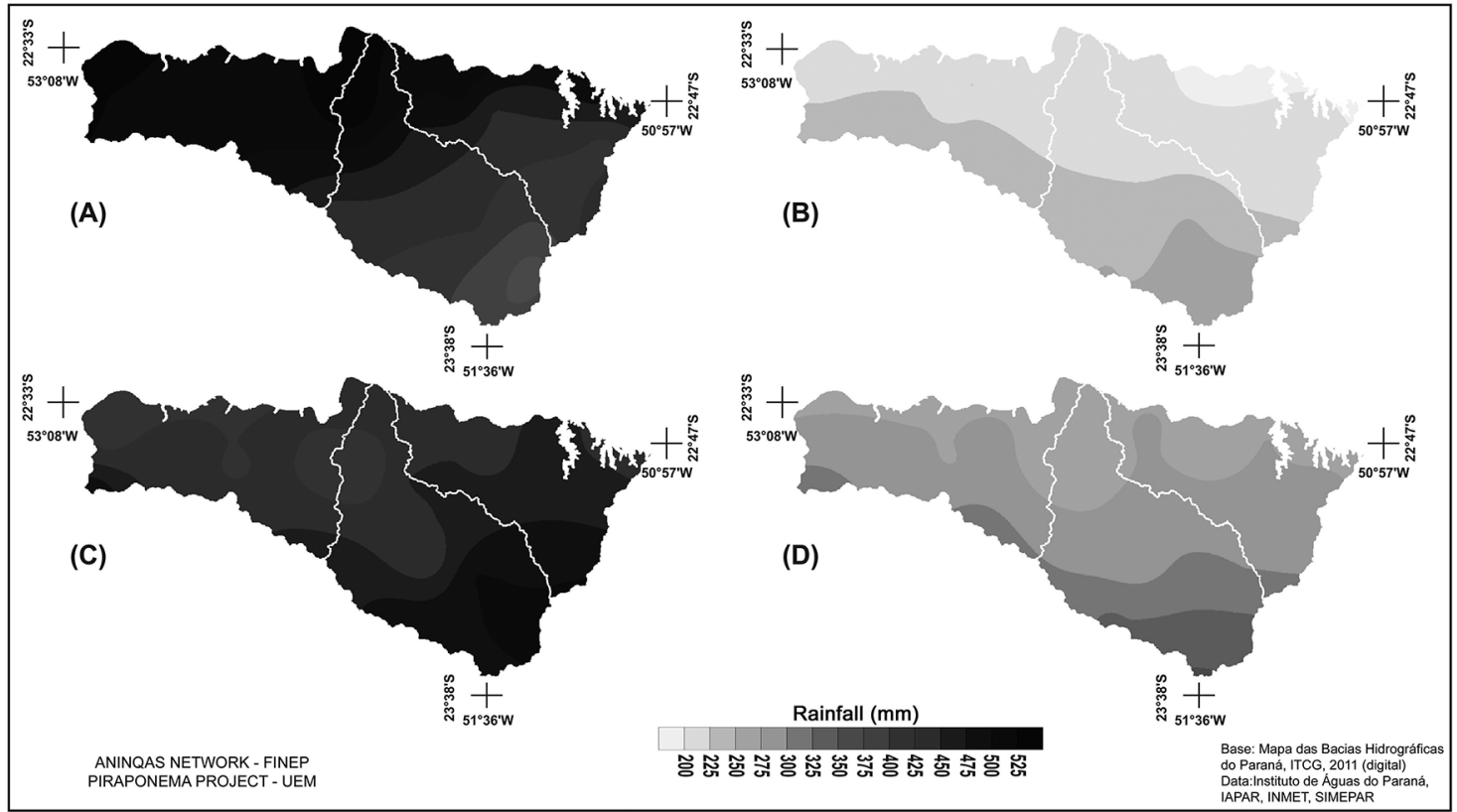

Figure 7. Spatial distribution of seasonal mean average rainfall in the Pirapó, Paranapanema 3 and Paranapanema4Hydrographic Unit from 1976 to 2012. (A) summer; (B) winter; (C) spring; (D) autumn. 
$460.4 \mathrm{~mm}$, during spring, followed by the Paranapanema 3 and 4 basins respectively with $450.2 \mathrm{~mm}$ and $436.2 \mathrm{~mm}$.

During autumn, the values were of $305.0 \mathrm{~mm}, 290.7 \mathrm{~mm}$ and $282.6 \mathrm{~mm}$ respectively for the Pirapó, Paranapanema 4 and Paranapanema 3 basins. The Pirapó basin was the wettest during the winter, with mean rainfall $238.7 \mathrm{~mm}$, followed by the Paranapanema 4 basin with $227.4 \mathrm{~mm}$ and by the Paranapanema 3 basin with $211.8 \mathrm{~mm}$.

December, January and February were the three wettest months in the hydrographic unit, whereas the driest ones were June, July and August. January is usually the month with the heaviest rainfall with a mean $185.9 \mathrm{~mm}$; the driest is August with $49.1 \mathrm{~mm}$

The effect produced by the relief on the rainfall distribution is also observed for the variation of mean annual temperatures: from $20.5^{\circ} \mathrm{C}$ to $23.5^{\circ} \mathrm{C}$ (Figure 8). Mean temperatures oscillate from $20.5^{\circ} \mathrm{C}$ to $21.0^{\circ} \mathrm{C}$ on the highest sections of the unit with altitudes higher than $800 \mathrm{~m}$ (Figure 3), especially at the headwaters of the Pirapó River. Maximum temperatures are higher, ranging of $23.0^{\circ} \mathrm{C}$ to $23.5^{\circ} \mathrm{C}$, in the north and northwest sectors with altitudes from $300 \mathrm{~m}$ to $350 \mathrm{~m}$ (Figure 3).

Summer (Figure 9A) and spring (Figure 9C) are the hottest seasons with mean temperatures varying from $22.5^{\circ} \mathrm{C}$ to $26.0^{\circ} \mathrm{C}$. Autumn (Figure 9D) and winter (Figure 9B) are the coldest seasons with mean temperatures varying from $18.5^{\circ} \mathrm{C}$ to $22.0^{\circ} \mathrm{C}$.

Climatic conditions, especially those referring to rainfall amount and distribution, directly affect the regimes of the streams and, therefore, the regional agricultural calendar, by alternating periods in which soils are extensively covered with crops and those with the highest soil exposures. The beginning of spring is characterized by extensive areas with exposed soil that is prepared for new crops. Even with the adoption of the no-till method, at that time, a significant portion of the straw covering was lost or transformed, allowing the action of erosion and consequent loss of soil. Soil loss on the hillslopes means an increase in particulate material that reaches the rivers. The solid particles not only reach the rivers more easily, but also bring with them, associated or dissolved, part of fertilizers and pesticides applied.

\subsection{Land occupation and use}

Successive forms of occupation and use that transformed the landscape and provided new characteristics to the dynamics and functioning should be seen within a wider regional context. The social, economic and historical records of human occupation and economical use of the land give an idea of the characteristics and historical process of the northern region of the state of Paraná, although the diverse compartments should be kept in mind.

Two relevant situations may be underscored when taking into consideration the northern region of the state of Paraná and the historical events of human occupation: the first event comprises activities from the late $19^{\text {th }}$ century and the second comprises activities from the 1930s. It was during the latter period that the north-central and northwestern mesoregions in which the Pirapó drainage basin and the Paranapanema 3 and Paranapanema 4 basins lie were developed. In the more recent phase, the north-central mesoregion was occupied first, followed by the northwestern one. The former was economically occupied and developed between the 1930s and 1940s, whilst the latter was developed in the 1950s and 1960s. The main similarities of the two mesoregions, which characterized the entire region of the northern Paraná, with few exceptions, were the coffee plantations that triggered economic progress. Due to the coffee cash crop and its economic advantages, populations from the states

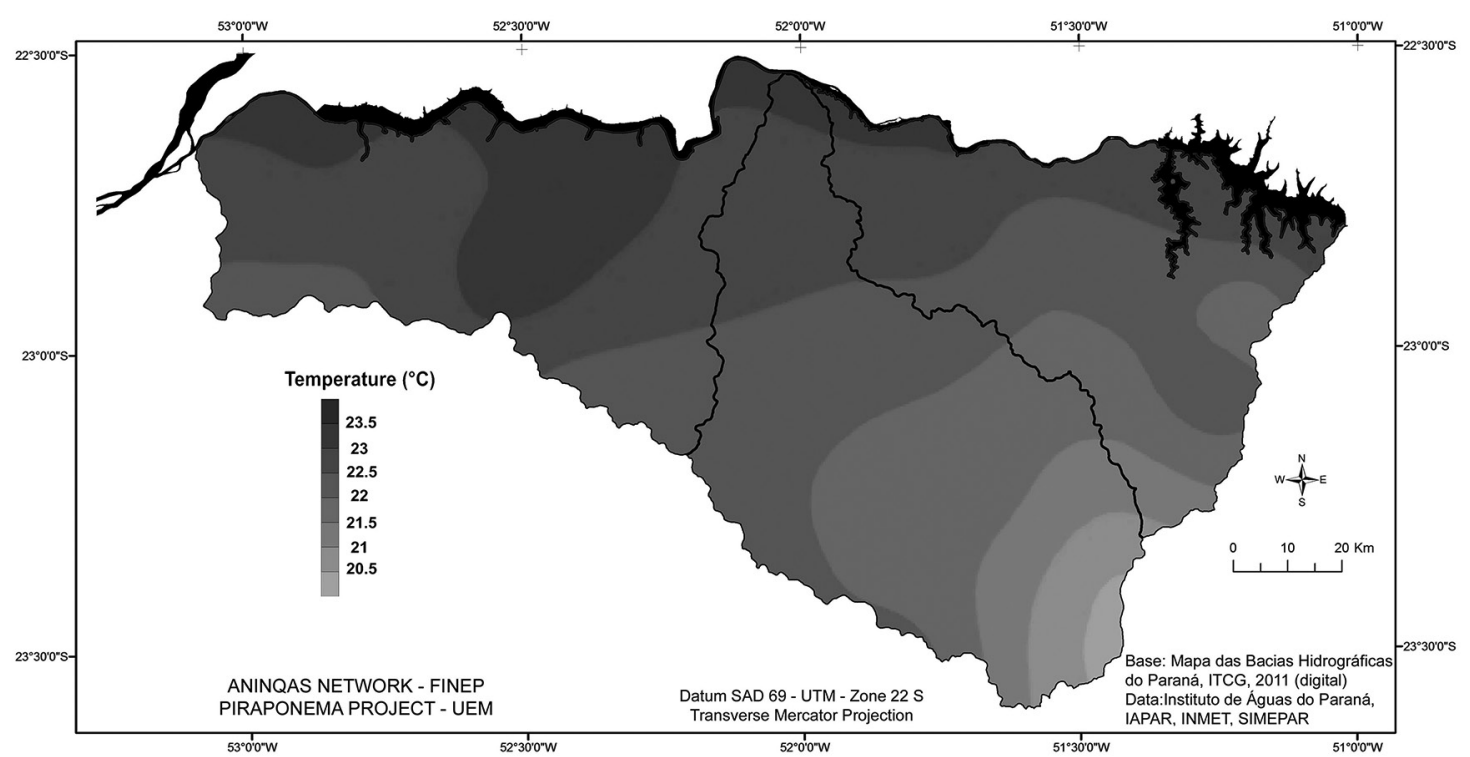

Figure 8. Spatial distribution of mean temperature in the Pirapó, Paranapanema 3 and Paranapanema 4 Hydrographic Unit from 1976 to 2012 . 


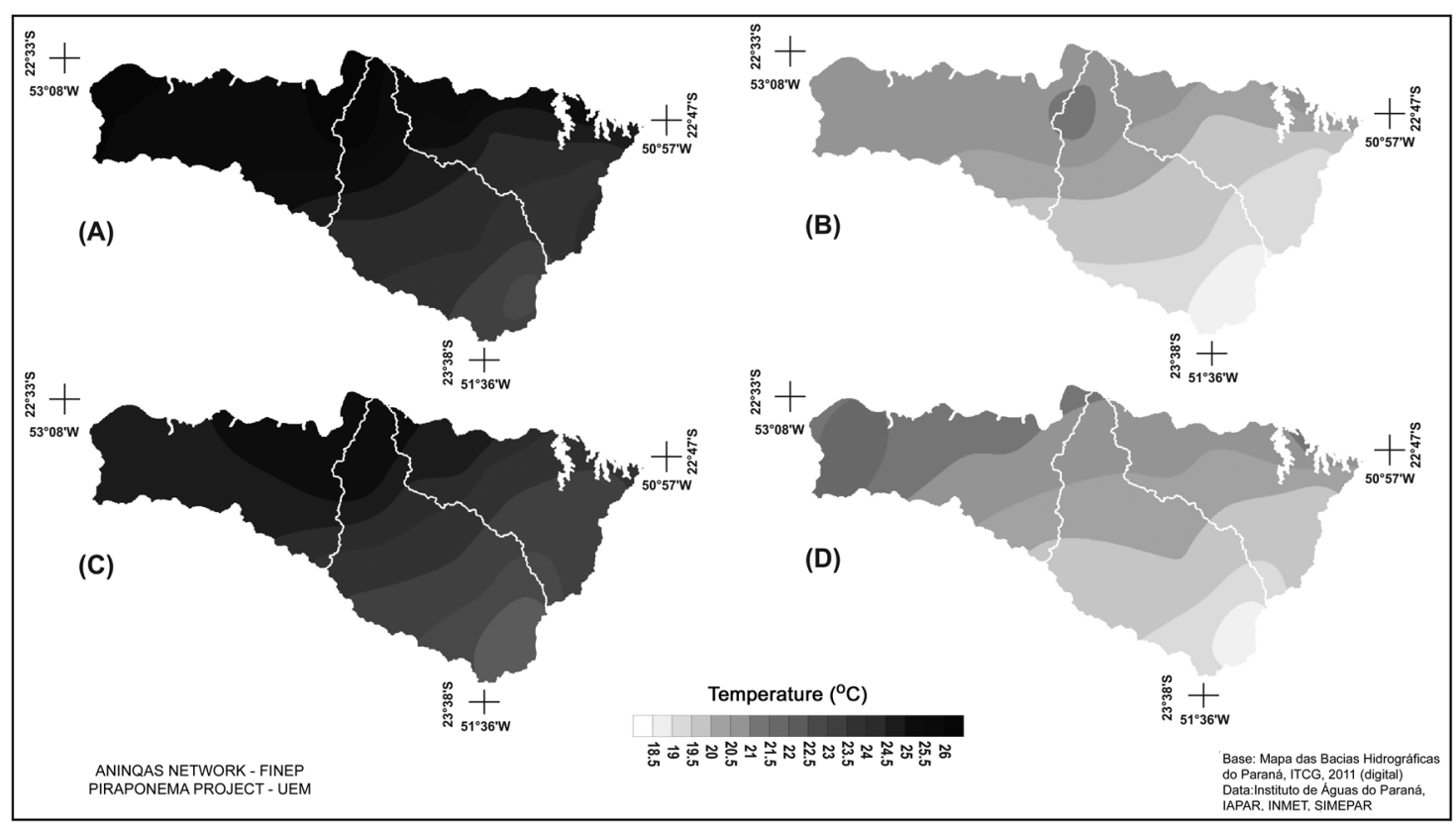

Figure 9. Spatial distribution of mean seasonal temperatures in the Pirapó, Paranapanema 3 and Paranapanema 4 Hydrographic Unit from 1976 to 2012. A) summer; (B) winter; (C) spring; (D) autumn.

of São Paulo and Minas Gerais became the inhabitants of the region as landowners and workers. Settlement due to private entrepreneurship was by far the main factor for the repartition and commercialization of land, while the settlement model followed standards established by real estate managers (Serra, 1991).

The pioneer settlement in the region ended in the 1960s, according to Serra et al. (2012), but the similarities of the spaces continued after the 1970s, when severe frosts, especially that in 1975 , destroyed the coffee plantation that propped the regional economy. Two new agricultural models, replacing the coffee plantation, emerged in the northern region of the state of Paraná as a whole and in the north-central and northwestern mesoregions. Whereas one agricultural model, predominant in the areas of soil that originated from basalts, featured mechanized soybean, maize and wheat crops, the other, predominant in the areas of sandstones derived soils, comprised pasture for the development of beef cattle. It should be underscored that, as from the 1990s, products that promoted the new agricultural models, especially pastureland, had to compete with sugarcane plantations predominantly in the sandstones zones.

Figure 10 shows current use of land in the hydrographic unit where the sections with the preferential occurrence of determined types of agriculture and cattle breeding activities may be distinguished. Pasture is predominant in sandstones areas (Caiuá, Santo Anastácio and Adamantina formations) and in medium texture soils, even though there is a trend for its substitution by sugarcane plantations associated with sugar and alcohol mills. Besides sugarcane plantations, manioc is extensively cultivated, especially in the Paranapanema 4 basin. Citrus (Paranapanema 4 basin) and annatto crops (Pirapó basin) are being developed in medium texture soils, even though only in specific areas and less extensively.

Grain crops, such as soybeans, maize and corn, are predominant in areas of clayey and very clayey texture soils in the Pirapó and in the Paranapanema 3 basins. However, pasture is extant in the upper valley of the Pirapó River where the terrain is more dissected; hillslopes are steeper and soils shallower. In spaces with flat topography that favors mechanization, other crops are developed even though in noncontinuous spaces and alternating with pasture. Further, sugarcane is frequently planted directly on horizon $\mathrm{C}$ (rock alteration material) and thus the landscape with extensive and uniform culture, common in areas of wide or mid-sized hills, is replaced by a mosaic landscape in which types of land use are highly varied.

Variation and distribution of land use is partially determined by the physical substratum (geology, landforms and soils) but they do not seem to be influenced by variations in climatic conditions in the basin. Conditions are not limiting for any of the aforementioned activities.

Strategy for urban space, according to Serra (1991), was developed by the real estate firm Companhia de Terras Norte do Paraná, which changed its name to Companhia Melhoramentos Norte do Paraná in the late 1940s. Towns were planned within the Londrina-Maringá and Maringá-Umuarama axes, approximately $15 \mathrm{~km}$ apart, with cities, such as Londrina, Maringá, Cianorte and Umuarama at an average distance of $100 \mathrm{~km}$ from one another. After fifty years have passed from the settlement phase, all the cities developed precisely as planned. Due to the intense urbanization process caused by the coffee plantation crisis and rural migration to towns in the late 1970s and early 


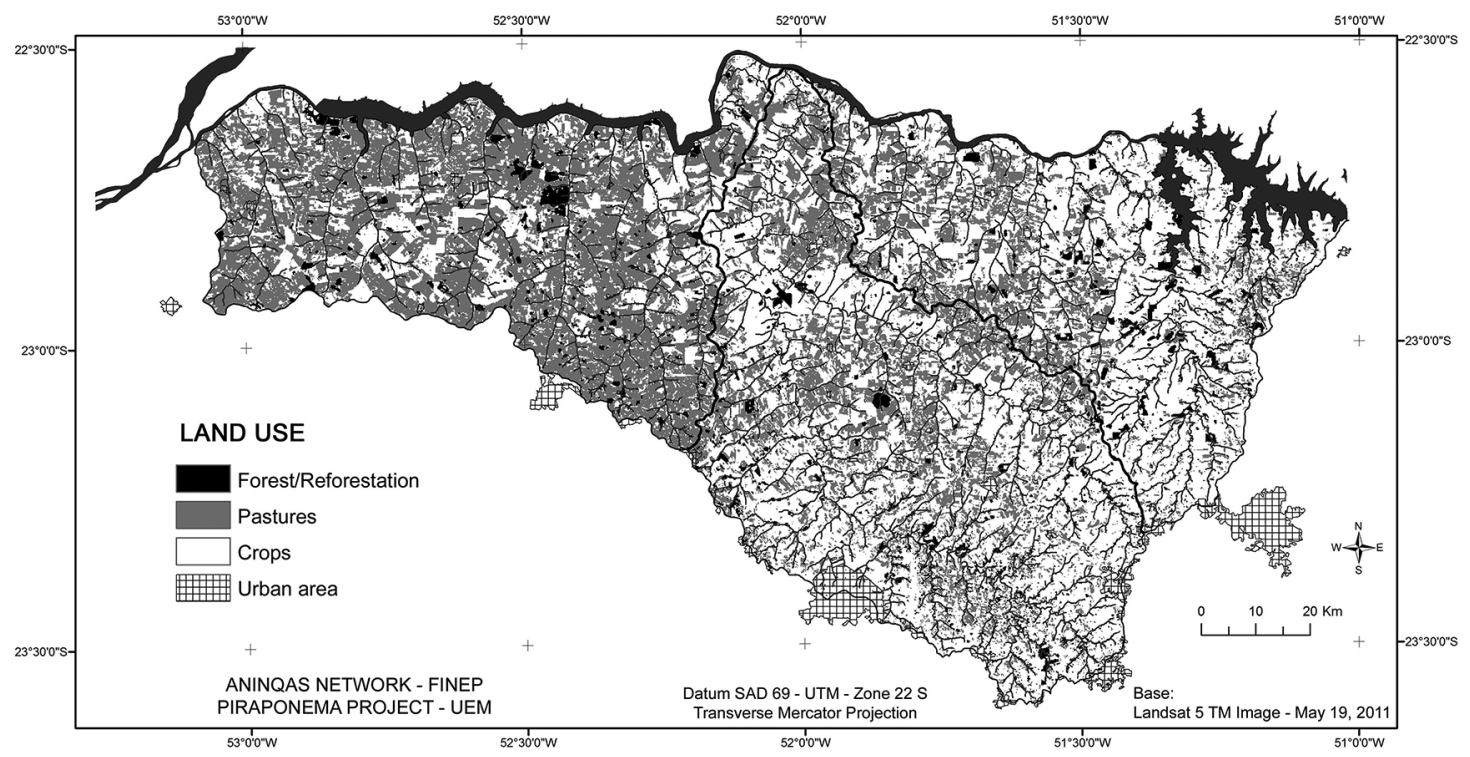

Figure 10. Map of land use of the Pirapó, Paranapanema 3 and 4 Hydrographic Unit.

1980s, the biggest cities, Londrina and Maringá, became metropolitan areas. Londrina's metropolitan zone also comprises many neighboring towns, such as Cambé and Rolândia, whilst the metropolitan zone of Maringá includes the city of Maringá and the neighboring towns of Marialva, Sarandi, Paiçandu and Mandaguaçu.

The metropolitan regions of Maringá and Londrina are only partially contained in the Pirapó, Paranapanema 3 and 4 Hydrographical Unit. The role of the metropolitan regions in the concentration of populations, services and commercial-industrial activities should be underscored, with great transformations in the environment and increase of demand for water resources. The effect is felt in the area of the main urban nucleus and its main neighboring towns. In the case of Maringá's metropolitan region, the urban site of Maringá and its neighboring towns, such as Sarandi and Marialva, lie within the limits of the Pirapó basin.

Contrastingly, Londrina is not part of the hydrographic unit and other towns such as Rolândia and Cambé are relatively distant one from another and distributed between the Pirapó and Paranapanema 3 basins. They lie on the top of the main watershed and their urban space is distributed between these basins and the Tibagi basin.

\subsection{Landscape structure}

Variations in the spatial structure of the landscape occur within each drainage basin in the regional scale analysis proposed by current research. Due to the composition of their more diversified geological substratum reflected in the characteristics of the pedological covering and still, in the case of the former, of an altitude variation, which establishes a more significant difference in climate condition, the internal compartmentalization of the Pirapó and Paranapanema 3 basins is easily detected. The Pananapanema 4 basin is more homogenous in several aspects but presents variations in drainage densities, in relief modeling and in the characteristics of the pedological systems that particularize sub-compartments. Figure 11 shows the landscape compartments identified by integrated analysis.

The Paranapanema 3 basin has two compartments:

- a sandstone compartment carved by three major drainage basins and by other small direct tributaries of the Paranapanema, with middle-sized to small hills, with pedological covering where Red Latosols are restricted to the top and the most significant sections of the hillsides are covered with Red Argisols, both of a medium/sandy texture. It is occupied with pastures and sugarcane plantations (Figure $11-1 \mathrm{a}$ ). As soils become rich in clay (Figure $11-1 b$ ), close to their contact with the basalt (in the bottom of certain valleys), the grain crops become extant;

- a basalt compartment drained by the Vermelho Creek basin (Figure 11 - 2) and formed by middle sized hills covered with clayey soils, underscoring the extension of Red Nitosols when compared to Red Latosols, both with ferric characteristics, preferentially occupied by grain crops (soybeans, maize and wheat). The main towns of the basin, namely Rolândia and Cambé, whose urban areas involve several headwaters of tributaries that form the Vermelho creek, lie in this Figure 11. Drainage basins and their landscape compartments

The Pirapó basin has two compartments:

- a sandstone compartment that comprises the lower section and part of the mid-basin (Figure 11 - 3). It is formed by wide to mid-sized hills with altitudes as low as $500 \mathrm{~m}$, covered with Red Latosols and Argisols with a medium/sandy texture. The basalt outcrops in the valleys of the main rivers (Pirapó and Bandeirantes) generating more clayey soils. Pastures 


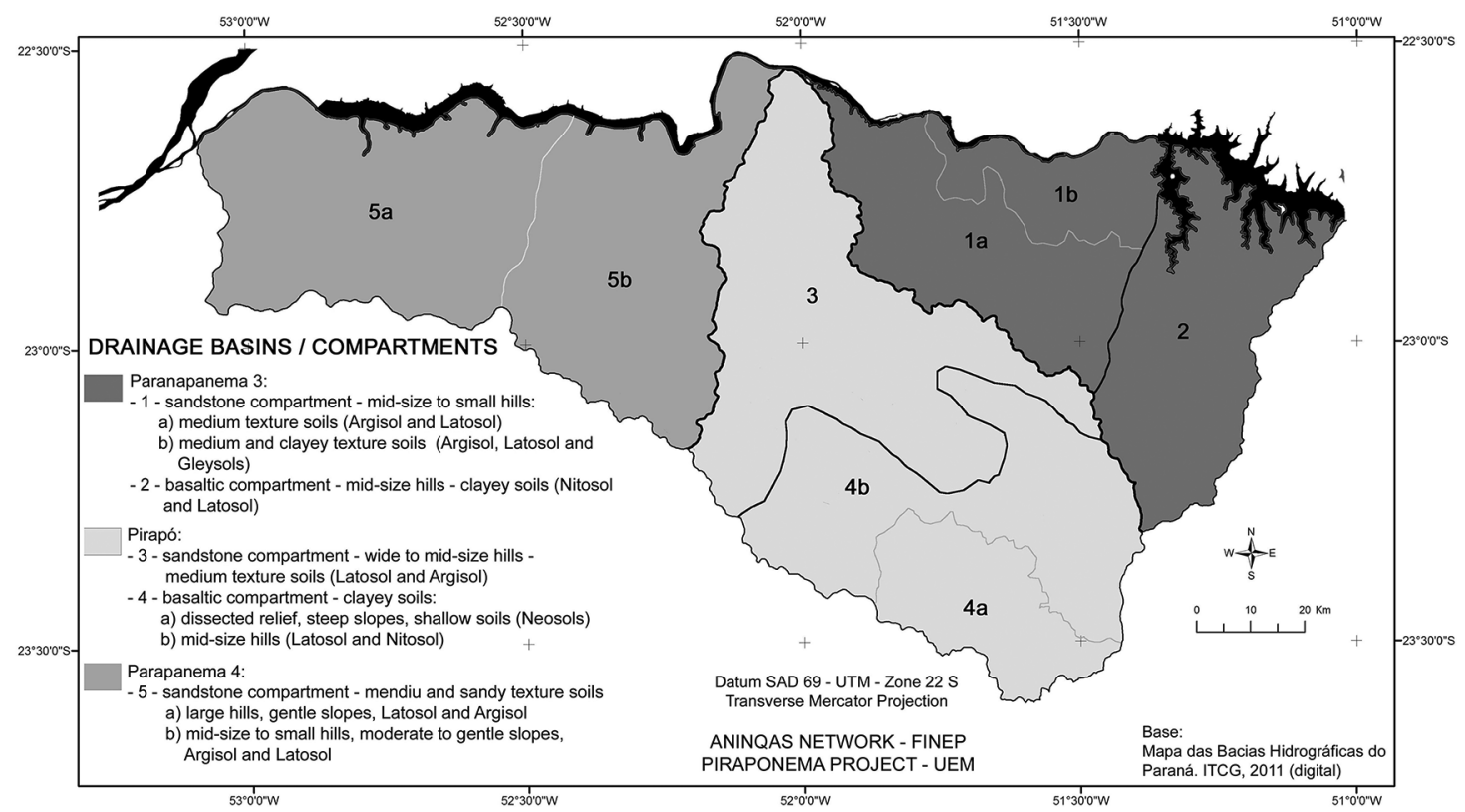

Figure 11. Drainage basins and their landscape compartments.

predominate with extensive and continuous areas of sugarcane and grain crops. More clayey soils in areas with basalt and/or in contact zones make possible the advance of grain crops in this compartment with topographic conditions for mechanization;

- a basalt compartment with a more diversified structure and internal physiognomy. In the upper course of the Pirapó River, on the left margin, relief is more dissected (Figure $11-4 a$ ). It is characterized by narrow hill tops, steep slopes with steps and covered by shallow soils (Litholic and/or Regolithic Neosols). The drainage network is denser and streams feature waterfalls, rapids and rebounds. Pastures are dominant, sometimes interrupted by small areas of grain crops, coffee or sugarcane plantations. The remaining section of the Pirapó basalt compartment (Figure 11 - 4b) presents a relief of mid-sized hills with rounded and wider tops, with altitudes exceeding $500 \mathrm{~m}$ and reaching more than $800 \mathrm{~m}$ at the watersheds. They are covered with dystroferric Red Latosols and eutroferric Red Nitosols, extensively occupied with grain crops (soybeans, maize and corn). Several towns (Maringá, Sarandi, Marialva, Mandaguari, Apucarana, Arapongas and others) are installed in their interfluves with numerous headwaters streams engulfed by urban sites. When compared to other compartments of the hydrographic unit, the highest parts of this compartment are relatively colder and wetter, with higher rainfall erosivity rates.

The Paranapanema 4 basin has one compartment:

- it is a big sandstone compartment composed only by the Caiuá Formation with a pedological covering of medium texture and sandy soils. However, a gradual increase in relief dissection from the western to the eastern section may be observed. It produces a narrowing of the hill top, decrease in the length of the hillsides and steeper slopes. Although the pedological system is still preferentially formed by Latosols-Argisols, such changes in the landscape are followed by increased incidence of Argisols that extend to higher positions on the hillslopes and eventually reach the top. Two sub-compartments are thus formed: on the west, limited by the watershed of the Coroa do Frade Creek (Figure 11 - 5a); on the east of the watershed till the limits with the Pirapó basin (Figure $11-5 b$ ). Pastures and manioc and sugarcane crops characterize soil use in the two sub-compartments. In the western sub-compartment, the replacement of pasture by sugarcane is a recent event, whereas in the eastern sub-compartment it is older. Citrus crops are also extant nearby. These differences are currently reflected in the erosion dynamics of the sub-compartments, with severe forms in the western sub-compartment due to the recent substitution of pastures.

The erosion is the most widespread kind of impact in all compartments, generating losses of large volumes of soil on hillsides and siltation and impairment of water quality when they reach water bodies. The sandstone compartments are generally more vulnerable to erosion than the basaltic compartments. In the last ones, however, the increased dissection of landforms and steeper slopes, as in the sub-compartment of upper Pirapó, also increases vulnerability to erosion (Bonifácio, 2013).

The surface coverage produced by different forms of land use, on the other hand, plays an important role 
both as to minimize and to facilitate the development of such processes.

Many writers report that pastures provide a more efficient coverage to the soil's surface, especially in areas with medium texture and sandy soils derived from sandstones. On one hand, if pasture minimizes the effect of runoff, on the other hand, inadequate management produces furrows and tracks due to cattle trampling, with the development of erosion due to surface water flows. Field observations indicate that headwaters areas are generally most affected. These processes generally start as furrows and ravines along the hollows, upstream of springs, in areas with more sandy soils, such as Quartzarenic Neosols and Argisols (horizons A and E). They evolve by regression on relatively more stable areas and soils while depositing large volumes of soil to the streams. However, in the case of adequate management of pasture, serious erosion forms are very rare.

The replacement of pastures by crops, especially by sugarcane tending towards a more continuous area and occupying greater land extensions than those by manioc crops, exposes soil surface to weathering during the preparation and planting, initial growth phases and harvest. The combination of these periods without or with deficient coverage at the start of the rainy period increases the susceptibility to soil erosion (Derpsch et al., 1991). As it has been verified on the field, during the first plantings there is a great mobilization of material from the surface layer of the soil exposed to water runoff that quickly reaches the streams. Increase in water turbidity and silting of the fluvial channels occur. In areas where replacement occurred in the past, especially those covered with Argisols, there has been complete removal of soil horizons (A and E), with the subsequent exposure of horizon B at the surface. Sediment deposits along the main watercourses appear vegetated and apparently stabilized in several places. It may be concluded that the exposure of horizon $\mathrm{B}$ favors the formation of water flow. However, cohesion, aggregation and dense conditions, partially due to clay rates higher than those of the upper horizons, already removed, cause relatively less soil losses. This means that a lower sediment load currently reaching the watercourses.

Paths and dirt roads should also be listed as important areas of sediment supply in sandstones compartments.

It should be underscored that the more severe erosion forms (gullies) in sandstones compartments frequently are seen on the peripheries of cities. They are produced by the dump without proper control of urban storm water runoff from upstream headwaters or along the slopes.

The seasonal grain crops, which prevail on basalt compartments, do not produce efficient and protective coverage of soil surface. Although clayey soils in these compartments are naturally more resistant to water erosion, the intensive use, especially with traditional centuries-old practices involving soil tilling, damages the soil. The compacting on the sub-surface layers and the structural instability of the surface layers, for example, favored the surface water runoff, with great soil losses
(Derpsch et al., 1991; Stone et al., 2006). Currently, on the other hand, the adoption of no-till practice ensures the permanence of soil organic material in the surface layer, benefits and provides greater stability to aggregation (structure) of the soil, improves the conditions for crop protection helping to reduce potentially erosive susceptibility associated with this form of use (crops).

Sediment loads that reach the water bodies are reduced when compared to that which occurred during the previous period and that which occurs today in compartments of medium texture soils. A better water quality in water bodies is thus obtained. In spite of this progress, during the wet period, the waters of the fluvial channels have high turbidity rates and reddish color that indicate significant loss of soils on the hillslopes.

Litholic and/or Regolithic Neosols areas in basalt compartments tend towards serious erosion processes. The occurrence of these shallow soils and of igneous rocks close to the surface does not favor the infiltration of rainwater, and, instead, leads towards a fast saturation of the material layer of altered rock and to the formation of surface water runoff (Bonifácio, 2013). This set of factors facilitates the installation and development of erosion, either as sheet erosion or as soil mass movements, highly frequent in these sectors, especially in pastures, enhanced by cattle trampling.

The influence of urbanization on the dynamics of watercourses in these compartments should also be underscored. The stretches of watercourses that pass through urban areas generally receive surface water runoff from the circulation pathways, frequently in an inadequate form that causes erosion, even in areas covered by forest vegetation, as within the parks in Maringá.

Besides the soil amount that reaches the watercourses, urban solid wastes composed of materials carried by the water flow and the effluents from several sources occur. These phenomena spread outside the urban perimeter, throughout the channels of the streams, decreasing in intensity and frequency as they go downstream when the impacts and problems that affect them turn out to be predominantly originated from agricultural and cattle-breeding activities on the hillslopes.

\section{Conclusions}

The integrated analysis of factors that form the geo-ecological structure of the landscape reveals that there are actually high similarities among the three basins (rocks, soils, landforms, and climate) that justify their treatment as a hydrographic unit. In spite of many similarities, however, each basin has its own peculiarities and forms distinct systems. The analysis also shows that variations in landscape structure occur in each basin that produces internal compartmentalization and thus sub-systems.

Compartmentalization in the basins of the hydrographic unit is mainly the result of a variation of geological substratum that place igneous rocks against sedimentary ones. Clayey texture soils and medium texture soils are respectively 
produced. Differentiated pedological systems on the same rock is also the result of drainage density and dissection degree that produce wider and milder landforms or more carved with steeper slopes that. Variations originating from the forms and conditions of settlement and land use are bonded to the variations of geo-ecological structure with the establishment of physiognomic and dynamic standards that individualize the compartments. Each compartment defines itself by a geo-ecological structure and by physiognomic and dynamic standards, reflected in its potentialities and vulnerabilities and in the conditions of its water resources in the face of occupation modes and use over time.

Landscape structure and its variations within each hydrographic basin contribute towards the monitoring of water resources by providing subsidies for the selection of watercourses, location of collection sites and the interpretation and generalization of results since they will be inserted in a subsystem limited by known attributes and dynamics.

From the management point of view, knowledge helps in decision-making and the application of measures for the management of water resources by providing information on the issues, their dimensions (spatialization), intensity and relationships with the functioning and the dynamics of factors that compose the landscape structure.

\section{Acknowledgements}

The FINEP for the financial support.

\section{References}

BIGARELLA, J.J. and MAZUCHOWSKI, J.Z., 1985. Visão integrada da problemática da erosão. In: Anais do $3^{\circ}$ Simpósio de Controle de Erosão, 1985, Maringá. Curitiba: ADEA-ABGE. 331 p. Livro Guia.

BONIFÁCIO, C.M., 2013. Avaliação da fragilidade ambiental em bacias hidrográficas do alto vale do rio Pirapó, Norte do Paraná: proposta metodológica. Maringá: Universidade Estadual de Maringá, 109 p. Masters Dissertation.

CUNHA, J.E., 2002. Funcionamento hídrico e suscetibilidade erosiva de um sistema pedológico constituído por Latossolo e Argissolo no município de Cidade Gaúcha - PR. São Paulo: Universidade de São Paulo, 175 p. PhD Thesis.

DERPSCH, R., ROTH, C.H., SIDIRAS, N. and KÖPKE, U., 1991. Controle da erosão no Paraná, Brasil: sistemas de cobertura do solo, plantio direto e preparo conservacionista do solo. Eschborn: GTZ-IAPAR. 272 p. Sonderpublikation der GTZ, no. 245.

EMPRESA BRASILEIRA DE PESQUISA AGROPECUÁRIA - EMBRAPA, 2008. Mapa de Solos do Estado do Paraná. Rio de Janeiro: Embrapa Solos, Embrapa Floresta. Escala 1:600.000. CD-ROM.

EMPRESA BRASILEIRA DE PESQUISAAGROPECUÁRIAEMBRAPA, 2013. Sistema Brasileiro de Classificação de Solos. 3rd ed. Brasília: Embrapa. 353 p.
FASOLO, O.J., CARDOSO, A., CARVALHO, A.P., HOCHMÜLLER, D.P., RAUEN, M.J. and PÖTTER, R.O., 1988. Erosão: inventário de áreas críticas no Noroeste do Paraná. Londrina: IAPAR. 19 p. Boletim Técnico, no. 23.

FERNANDES, L.A., 1998. Estratigrafia e evolução geológica da parte oriental da Bacia Bauru (Ks, Brasil). São Paulo: Instituto de Geociências, Universidade de São Paulo, 216 p. PhD Thesis.

KER, J.C., 1998. Latossolos do Brasil: uma revisão. Geonomos, vol. 5, no. 1, pp. 17-40.

MELFI, A.J., PICCIRILLO, E.M. and NARDY, A.J.R., 1988. Geological and magmatic aspects of the Paraná basin: an introduction. In: E.M. PICCIRILLO and A.J. MELFI, eds. The Mesozoic flood volcanism of the Paraná basin. São Paulo: Instituto Astronômico e Geofísico, Universidade de São Paulo, pp. 1-13.

OMETTO, J.C., 1981. Bioclimatologia vegetal. São Paulo: Agronômica Ceres. 425 p.

PARANÁ. Secretaria de Estado do Meio Ambiente e Recursos Hídricos - SEMA, 2010. Bacias hidrográficas do Paraná. Curitiba. 138 p.

PAULA-SILVA, F., CHANG, H.K. and CAETANO-CHANG, M.R., 2003. Perfis de referência do Grupo Bauru (K) no estado de São Paulo. Geociências, vol. 22, pp. 21-32.

PICCIRILLO, E.M., COMIN-CHIARAMONTI, P., MELFI, A.J., STOLFA, D., BELLIENI, G., MARQUES, L.S., GIARETTA, A., NARDY, A.J.R., PINESE, J.P.P., RAPOSO, M.I.B. and ROISENBERG, A., 1988. Petrochemistry of continental flood basalt-rhyolite suites and related intrusives from the Paraná Basin (Brazil). In: E.M. PICCIRILL and A.J. MELFI, eds. The Mesozoic flood volcanism of the Paraná basin. São Paulo: Instituto Astronômico e Geofísico, Universidade de São Paulo, pp. 107-156.

ROSS, J.L.S., 1994. Análise empírica da fragilidade dos ambientes naturais e antropizados. Revista do Departamento de Geografia, no. 8, pp. 63-74.

SERRA, E., 1991. Processos de ocupação e a luta pela terra agrícola no Paraná. Rio Claro: Universidade Estadual Paulista. $\mathrm{PhD}$ Thesis.

SERRA, E., NÓBREGA, M.T. and ANDRADE, J.A., 2012. Paisagem, estudo de caso no espaço agrário do Noroeste do Paraná. Revista da Anpege, vol. 8, no. 10, pp. 85-99. http://dx.doi. org/10.5418/RA2012.0810.0006.

SERVIÇO GEOLÓGICO DO PARANÁ - MINEROPAR, 2001. Atlas comentado da geologia e dos recursos minerais do estado do Paraná. Curitiba: MINEROPAR. 116 p.

SERVIÇO GEOLÓGICO DO PARANÁ - MINEROPAR, 2006. Mapa geológico do Paraná. Curitiba: MINEROPAR. 1 Mapa. Escala 1:650.000.

STONE, L.F., SILVEIRA, P.M. and MOREIRA, J.A.A., 2006. Atributos fisico-hidricos do solo sob plantio direto. Santo Antonio de Goiás: Embrapa Arroz e Feijão. 39 p. Documentos, no. 191.

VALERIANO, M.M., 2008. Topodata: guia para a utilização de dados geomorfológicos locais. São José dos Campos: INPE. 72 p. INPE-15318-RPQ/818.

WORLD SOIL RESOURCE - WRB, 2006. World reference base for soil resources. Rome: FAO. 128 p. World Soil Resource Reports, no. 103. 